\title{
Systematic mapping of the Archaean basement in the Fiskenæsset region, southern West Greenland
}

\section{Feiko Kalsbeek}

The systematic mapping of the Fiskenæsset region, which began in 1970 (see previous GGU Report of Activities) was completed between June and September 1975. The work was hampered by relatively poor weather. Apart from the writer, the following geologists took part in the field work: J. C. Escher (GGU), J. S. Myers (GGU), O. Stecher (Århus University) and J. Tomas (Geol. Surv. Prague). R. T. Pidgeon (Scottish Universities Research Reactor Centre, East Kilbride) collected more material for isotope work, and H. R. Cooke (GGU) made a brief survey of the chromite deposits. Much of the work of this summer consisted of checking previously mapped areas and of correlating rock types between different parts of the region.

As on previous occasions the field parties were served by two Bell helicopters chartered from Heliswiss (Berne) and the GGU cutter J. F. Johnstrup, operating from the base camp

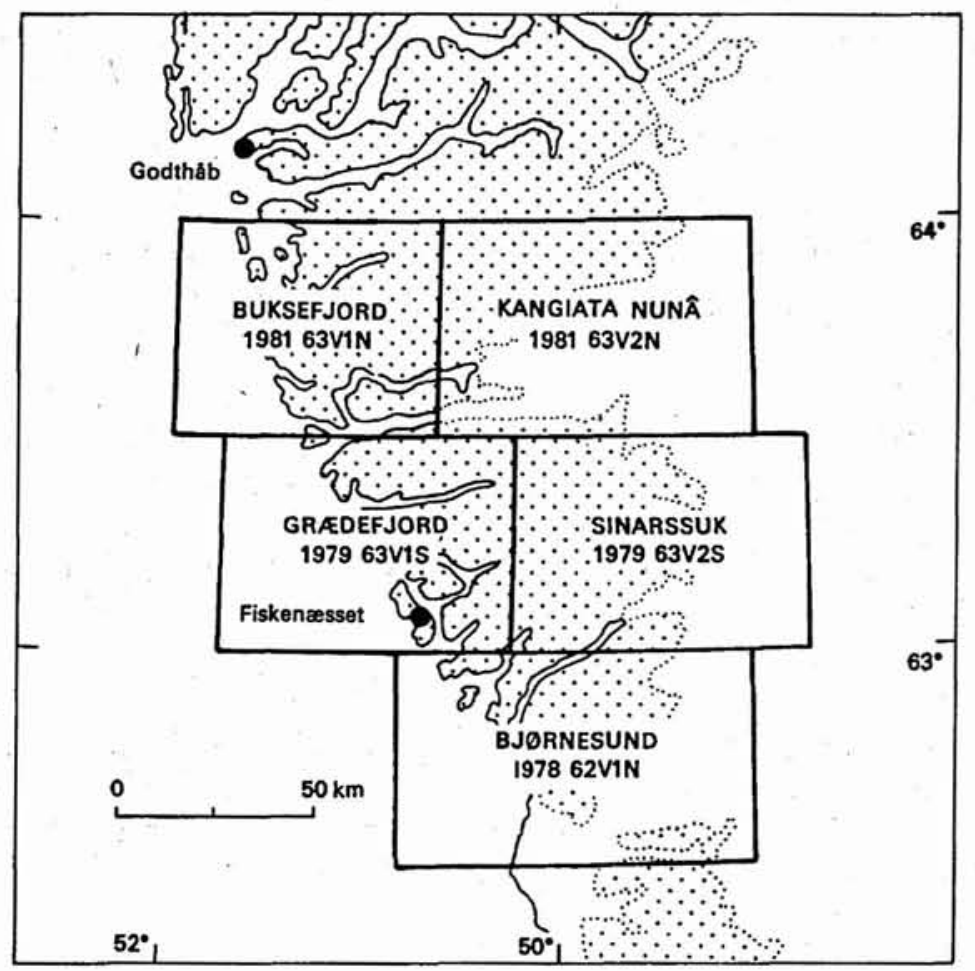

Fig. 27. Names and location of the 1:100 000 map sheets of the Fiskenæsset region, southern West Greenland with the expected year of publication. 
Midgård. Geologists from Exeter University mapping the Buksefjorden map sheet (Coe $e t$ al., this report) were also supported from Midgård. Ib Olsen (GGU) took care of most of the practical arrangements. The work from 1970-1975 in the Fiskenæsset region will be published as four 1:100 000 map sheets (fig. 27). Field work on the Buksefjorden map sheet will continue until 1977.

Recent results of field and laboratory investigations have been published in two progress reports (Rapp. Grønlands geol. Unders. 51, 1973 and 73, 1976) and little needs to be added here.

The existence of very old gneisses, comparable to the Amitsoq gneisses in the Godthåb area, has not been proven even in the northernmost part of the area near $64^{\circ} \mathrm{N}$. Isotope work of R. T. Pidgeon (Pidgeon \& Hopgood, 1975; Pidgeon, personal communication, 1975) has shown that gneiss formation and metamorphism in the southern part of the Fiskenæsset area probably started around $3000 \mathrm{~m}$.y. and continued to around $2650 \mathrm{~m} . \mathrm{y}$. The Ilivertalik granite near Midgård has been dated at $2800 \mathrm{~m} . \mathrm{y}$. and was probably intruded during the granulite facies metamorphism.

The rocks in the northern part of the area are partly in high amphibolite facies and partly in hornblende-granulite facies. Hypersthene seems to be irregularly distributed. Contrary to earlier opinion, it now seems most probable that the amphibolite facies rocks in the southern part of the area have never been in granulite facies. Correlation and comparison of anorthosite layers throughout the Fiskenæsset area by J. S. Myers (Myers, this report) has resulted in a better understanding of the overall stratigraphy of the Fiskenæsset complex.

\title{
Field mapping of nunatak $1390 \mathrm{~m}$, east of Alángordlia, southern West Greenland
}

\author{
Jan C. Escher and Robert T. Pidgeon
}

In August 1975 nunatak $1390 \mathrm{~m}$, situated just south of $63^{\circ} 45^{\prime} \mathrm{N}$ and east of the glacier Sermilik, was visited by J. C. E., who completed mapping it and by R. T. P., who collected samples for geochronological work. The nunatak had been previously visited by J. C. E., Poul Holm and Celina Zetterstrøm.

\section{Rock types}

The main rock types composing the bedrock are amphibolite, grey gneiss, augen gneiss, muscovite-bearing gneiss, and porphyritic granite. Also present are grey dykes of intermediate composition and porphyritic dykes which are restricted to the amphibolite and the grey gneiss. Much of the nunatak is covered with moraine and talus.

\section{Amphibolite}

The amphibolite locally shows well preserved pillow lava structures with vesicules along the chilled margins of the pillows. A summarised description has been given by Escher \& 